\title{
The influence of sex ratio on the reproduction of pirarucu, Arapaima gigas, in captivity
}

\author{
Adriana Ferreira LIMA \\ Empresa Brasileira de Pesquisa Agropecuária, Embrapa Pesca e Aquicultura, Av. NS 10 com a Av. LO 18, Lot. Água Fria, Palmas, Tocantins, Brazil \\ Corresponding author: adriana.lima@embrapa.br
}

\section{ABSTRACT}

Because sex ratio in the broodstock can influence the reproductive behaviour of a species, the influence of sex ratio on the reproductive success of pirarucu, Arapaima gigas, in captivity was assessed. Pirarucu breeders were stocked in $0.10-0.13$ ha earthen ponds at three sex ratios in quadruplicate: one male to one female (1M1F); one male to two females (1M2F); and two males to one female (2M1F). Eight spawning events occurred, seven of them with the $1 \mathrm{M} 1 \mathrm{~F}$ sex ratio, which was the most successful of the three tested sex ratios.

KEYWORDS: breeding pairs, mating, tropical fish cultivation

\section{Influência da proporção sexual na reprodução do pirarucu, Arapaima gigas, em cativeiro}

\section{RESUMO}

A proporção sexual de reprodutores pode influenciar o comportamento reprodutivo de uma espécie. Em função disso, avaliouse o efeito da estocagem de reprodutores em diferentes proporçóes sexuais no sucesso reprodutivo do pirarucu, Arapaima gigas, em cativeiro. Reprodutores foram estocados em viveiros de 0,10-0,13 ha, distribuídos em três tratamentos (proporções sexuais), com quatro repetiçóes cada: (1M1F) um macho e uma fêmea, (1M2F) um macho e duas fêmeas; e (2M1F) dois machos e uma fêmea. Foram observadas oito desovas, sendo a proporção sexual 1M1F a mais eficiente, apresentando sete desovas. Sugere-se, portanto, que a proporção sexual de um macho para cada fêmea é mais adequada para a reprodução do pirarucu em cativeiro.

PALAVRAS-CHAVE: acasalamento, reprodutores, peixes, aquicultura tropical 
Pirarucu, Arapaima gigas, is one of the emblematic native fish species of the Amazon, mainly because of its large size. It is typically more than $3 \mathrm{~m}$ long and weighs approximately $200 \mathrm{~kg}$ (Saint-Paul 1986). Historically, pirarucu has been consumed by the Amazonian riverine human population and subjected to considerable fishing pressure, which has led to the depletion of wild populations and its listing as an endangered species by Convention on International Trade in Endangered Species of Wild Fauna and Flora. The aquaculture of pirarucu may be a solution to provide fish to growing consumer markets and reduce the pressure on wild populations of the species.

Pirarucu has high potential for aquaculture due its fast growth, tolerance to low concentrations of oxygen, high fillet yield, no intramuscular spines, and mild flavour (Saint-Paul 1986; Imbiriba 2001; Fogaça et al. 2011). Nevertheless, production is limited by low availability of fingerlings and high cost, as information on its reproductive biology is scarce.

Pioneering studies on the reproductive biology of pirarucu in captivity provide information on pair formation for mating, nest digging and parental care (Fontenele 1948). In captivity, the spawning of pirarucu has been reported in different types and sizes of ponds and river dams, with breeders stocked in pairs or in groups (Núnez et al. 2011; Farias et al. 2015). Breeders stocked in pairs in a smaller pond resulted in more spawning events than those stocked with more breeders in a larger pond or dam (Farias et al. 2015). Therefore, stocking fewer individuals per pond should allow for the most efficient use of a pirarucu broodstock. However, this is still an incipient practice among pirarucu commercial farmers (Rebellato-Júnior et al. 2015).

Little information is available on the role of sex ratio in sexual selection, mating behavior, breeding pair formation and spawning in pirarucu. Thus, this study assessed the effect of different sex ratios on the reproductive success of pirarucu in captivity.

The study was carried out at a commercial farm in the northern Brazilian Amazon (Fazenda Paraíso de Deus, municipality of Amajari, state of Roraima, $3^{\circ} 17^{\prime} 17,49^{\prime \prime} \mathrm{N}$, $\left.61^{\circ} 26^{\prime} 31,15^{\prime \prime} \mathrm{W}\right)$ between May 2014 and December 2015. Pirarucu breeders from the same origin had been reared at the farm for four years since the juvenile stage. Individuals were captured with a dragnet and measured, and blood samples were collected for sex determination by the presence of vitellogenin (Chu-Koo et al. 2009) using a commercial kit $\left(\right.$ Acobiom $\left.{ }^{\oplus}\right)$. Breeders were stocked in twelve earthen ponds with $0.10-0.13$ ha surface area and $1.8 \mathrm{~m}$ deep, located side by side. The ponds were filled with water from a water reservoir on the property, and the water surface of the ponds was free from vegetation during the study period. The experimental design included three sex ratios with four replicates (ponds) each: one male to one female (1M1F) (two fish per pond), one male to two female (1M2F) (three fish per pond), and two males to one female (2M1F) (three fish per pond). In a pool of fish with the same age were chosen those with similar length to form each replicate.
Each fish was fed daily with $250 \mathrm{~g}$ of a commercial feed for carnivorous species with $40 \%$ crude protein. Additionally, once a week, $500 \mathrm{~g}$ of foraging fish was fed to each individual as a complement to the artificial diet, as the commercial feeds available are below the nutritional requirements of Brazilian native species (Cyrino et al. 2010), including pirarucu. During the study, pond water was not replaced, only added when lost by evaporation and infiltration. The presence of foraging fish in the ponds was observed during the study period.

Reproductive events were detected with the observation of offspring emerging to water surface to breath and were recorded as reproductive success. The behaviour was observed every day when fish were fed. When one fish was eventually isolated in an area of the pond and aggressions were observed, it was recorded as an aggressive behaviour. Data of reproductive success were classified in contingency tables and analysed by Fisher's exact test at a significance level of 5\% using R statistical software (R Core Team 2015).

The reproductive success of pirarucu is influenced by the sex ratio in the experimental conditions. Eight spawning events occurred during the study period, seven of which in the $1 \mathrm{M} 1 \mathrm{~F}$ ponds and one in one $2 \mathrm{M} 1 \mathrm{~F}$ pond. The spawning event in the $2 \mathrm{M} 1 \mathrm{~F}$ pond occurred after one of the males died due to aggressive behaviour between the breeders and this fish was not substituted. Reproductive success was significantly higher in the $1 \mathrm{M} 1 \mathrm{~F}$ ponds $(\mathrm{p}<0.05)$.

The first spawning event occurred in the $2 \mathrm{M} 1 \mathrm{~F}$ pond in July 2014, 39 days after the mating pairs were stocked. The other spawning events were concentrated in the rainy season, between April and September 2014 and 2015 (Table 1). The concentration of pirarucu spawning in the rainy season was also observed in a natural environment (Queiroz 2000) and in captivity (Núñez et al. 2011). Two pairs in 1M1F ponds spawned more than once in one reproductive cycle, with a 60day and 65-day interval, respectively, between them (Table 1).

Pirarucu spawning events have been reported in small earthen ponds $\left(200 \mathrm{~m}^{2}\right)$ (Fontenele 1948), in $400-\mathrm{m}^{2}$ ponds stocked with two breeders (Farias et al. 2015), and in ponds similar in size to those used in this study (Imbiriba 2001). Thus, pond area does not seem to influence the occurrence of reproductive bouts of pirarucu in captivity.

The occurrence of more spawning events in the ponds with one pair of breeders in 1:1 sex ratio suggest that it may be more adequate for the reproduction of pirarucu in captivity, because unbalanced in the reproductive sex ratio increases mating competition (Forsgren et al., 2004). Intense competition may be understood not only as an increase in violent attacks but also as the inhibition of mating (Kvarnemo and Anhesjo 1996). The addition of a male or female intruder to a pair increased in reproduction indices in the monogamous Cichlassoma cyanoguttatum (Itzkowitz and Draud 1992), 
Table 1. Number of spawning events that occurred in 12 experimental ponds stocked with pirarucu, Arapaima gigas breeders at different sex ratios from May 2014 to December 2015. Sex ratio: 1M1F (one male to one female); 1M2F (one male to two females); 2M1F (two males to one female).

\begin{tabular}{|c|c|c|c|c|c|c|}
\hline \multirow{2}{*}{ Sex ratio } & \multirow{2}{*}{ Pond } & \multicolumn{2}{|c|}{ Total body length $(\mathrm{cm})$} & \multirow{2}{*}{ Spawning events } & \multirow{2}{*}{$\begin{array}{l}\text { Time until first spawning } \\
\text { (days) }\end{array}$} & \multirow{2}{*}{$\begin{array}{l}\text { Interval between } \\
\text { spawnings (days }\end{array}$} \\
\hline & & Males & Females & & & \\
\hline $1 \mathrm{M} 2 \mathrm{~F}$ & 1 & 148 & 166,163 & 0 & - & - \\
\hline $1 \mathrm{M} 2 \mathrm{~F}$ & 2 & 155 & 150,161 & 0 & - & - \\
\hline $1 \mathrm{M} 2 \mathrm{~F}$ & 3 & 166 & 173,160 & 0 & - & - \\
\hline $1 \mathrm{M} 2 \mathrm{~F}$ & 4 & 129 & 129,130 & 0 & - & - \\
\hline $2 \mathrm{M} 1 \mathrm{~F}$ & 5 & 164,144 & 139 & 1 & 39 & - \\
\hline $2 \mathrm{M} 1 \mathrm{~F}$ & 6 & 155,150 & 161 & 0 & - & - \\
\hline $2 \mathrm{M} 1 \mathrm{~F}$ & 7 & 177,160 & 160 & 0 & - & - \\
\hline $2 \mathrm{M} 1 \mathrm{~F}$ & 8 & 151,144 & 135 & 0 & - & - \\
\hline $1 \mathrm{M} 1 \mathrm{~F}$ & 9 & 166 & 133 & 1 & 384 & - \\
\hline $1 \mathrm{M} 1 \mathrm{~F}$ & 10 & 151 & 143 & 3 & 123 & 291 and 60 \\
\hline $1 \mathrm{M} 1 \mathrm{~F}$ & 11 & 156 & 136 & 1 & 88 & - \\
\hline $1 \mathrm{M} 1 \mathrm{~F}$ & 12 & 167 & 156 & 2 & 400 & 65 \\
\hline
\end{tabular}

yet the same strategy did not promote reproduction of the pirarucus in the present experiment.

For most fish species, the reproductive success of males is influenced by access to females, and the competition among individuals for mates, while in females reproductive success is limited by access to resources (Rios-Cardenas and Morris 2009). In this study, stocking an additional male resulted in intense aggressive behavior in on one of the four ponds, that resulted in a male fish death, corroborating the typical behavior when females are limited (Rios-Cardenas and Morris 2009). Aggressive behaviour has also been observed when an additional female was stocked (1M2F). No aggressive behaviour was observed when only one pair was stocked in the pond. The aggressive behaviour resulting in death is different from that shown by the species in a natural environment, where the fish has the possibility of escape (Itzkowitz and Draud 1992).

Physical aggression between breeders of pirarucu in captivity had previously been reported by Fontenele (1948). It is probably relates to the dispute for dominance of the reproductive ground. The aggressive behaviour among fish may also occur when sexually active conspecifics are more abundant than the opposite sex, acting as a mechanism of attraction for mating (Forsgren et al. 2004). Thus, competition may occur among females or males, depending on their relative abundance. This may explain the disputes observed when the sex ratio of pirarucus was skewed, leading males or females to dispute the favour of the single conspecific and/or protect the spawning site.

A mating system is defined as a species-specific malefemale association pattern (Rios-Cardenas and Morris 2009). Pirarucu had been defined as a monogamous species (Fontenele 1948), however, recent evidence has been produced that the species may be polygamous (Farias et al. 2015). In monogamy, males are the main competitor to mate (Sogabe and Yanagisawa 2007), whereas in polygamous animals, competition may occur in both sexes (Rios-Cardenas and Morris 2009). Aggressive behavior observed between both females and males in this study reinforces the possible polygamy hypothesis in pirarucu.

The present study confirmed pirarucu as a multiple spawner with successive spawning in one reproductive cycle (Fontenele 1948), and that pirarucu in captivity maintain the same spawning characteristic as in the natural environment (Queiroz 2000). Spawning frequency is influenced by natural productivity, mainly through the provision of adequate food supply to the larvae (McEvoy and MCEvoy 1992). In the present study, only two pairs spawned two consecutive times during the reproductive cycle. Second spawnings occurred after the fingerlings were removed from parental care. At the end of the parental care, female pirarucu were able to spawn again in very near future, while male could be thin if taking care fingerling until they achieve $35-40 \mathrm{~cm}$ (Farias et al. 2009). As in this study fingerling were removed as soon as they were observed in ponds, males were in suitable conditions to spawn again. The first spawning 39 days after the pairing of potential breeders, suggests that conditions in the ponds were sub-optimal for pirarucu and should be further investigated for determination of optimal environmental conditions to maximize the reproductive potential and productivity of pirarucu in captivity.

In conclusion, as stocking three fish in an unbalanced sex ratio of 1:2 may result in fish mortality, the results suggest that maintaining only a couple of fish within a sex ratio of 1:1 per pond improves the reproduction of pirarucu in captivity. Besides, broodstock management in captivity needs improvements to allow multiple spawning events in every reproductive cycle. 


\section{ACKNOWLEDGMENTS}

This study was funded by Ministério de Agricultura, Pecuária e Abastecimento - MAPA, through Conselho Nacional de Desenvolvimento Científico e Tecnológico (457465/2012-3), and by Serviço Brasileiro de Apoio à Micro e Pequenas Empresas (2538/2012). The author is grateful to Mr. A.C. Wanderley Neto for providing the breeders and farm infrastructure, and to Ms. R.R. Alves for the assistance in the statistical analysis.

\section{REFERENCES}

Chu-Koo, F.; Dugué, R.; Alván Aguilar, M.; Casanova Daza, A.; Alcántara Bocanegra, F; Chávez Veintemilla, C.; Duponchelle, F.; Renno; J.F.; Tello, S.; Núńez, J. 2009. Gender determination in the Paiche or Pirarucu (Arapaima gigas) using plasma vitellogenin, 17-estradiol, and 11-ketotestosterone levels. Fish Physiology and Biochemistry, 35: 125-136.

Cyrino, J.E.P.; Bicudo, A.J.A.; Sado, R.Y.; Borghesi, R.; Dairiki, J.K. 2010. A piscicultura e o ambiente - o uso de alimentos ambientalmente corretos em piscicultura. Revista Brasileira de Zootecnia, 39: 68-87.

Farias, I. P.; Leão, A. S. D. A.; Almeida, Y. S.; Verba, J. T.; Crossa, M.; Honczaryk, A.; Hrbek, T. 2015. Evidence of polygamy in the socially monogamous Amazonian fish Arapaima gigas (Cuvier, 1817). Neotropical Ichthyology, 13: 195-204.

Fogaça, F.H.D.S.; Oliveira, E.G.; Carvalho, S.E.Q.; Santos, J.F.D.S. 2011. Yield and composition of pirarucu fillet in different weight classes. Acta Scientiarum. Animal Sciences, 33: 95-99.

Fontenele, O. 1948. Contribuição para o conhecimento da biologia do Pirarucu, "Arapaima gigas" (Cuvier), em cativeiro (Actinopterygii, Osteoglossidae). Revista Brasileira de Biologia, 4: 445-459.

Forsgren, E.; Amundsen, T.; Borg, A.A.; Bjelvenmark, J. 2004. Unusually dynamic sex roles in a fish. Nature, 429: 551-554.

Imbiriba, E.P. 2001. Potencial de criação de pirarucu em cativeiro. Acta Amazonica, 31: 299-316.
Itzkowitz, M.; Draud, M.J. 1992. Conspecific intruders influence pair formation in a monogamous fish. Behavioural Processes, 28: 59-64.

Kvarnemo, C.; Ahnesjo, I. 1996. The dynamics of operational sex ratios and competition for mates. Trends in Ecology \& Evolution, 11: 404-408.

McEvoy, L.A.; McEvoy, J. 1992. Multiple spawning in several commercial fish species and its consequences for fisheries management, cultivation and experimentation. Journal of Fish Biology, 41: 125-136.

Núñez, J.; Chu-Koo, F.; Berland, M.; Arévalo, L.; Ribeyro, O.; Duponchelle, F.; Renno, J.F. 2011. Reproductive success and fry production of the paiche or pirarucu, Arapaima gigas (Schinz), in the region of Iquitos, Perú. Aquaculture Research, 42: 815-822.

Queiroz, H. L. De. 2000. Natural History and Conservation of Pirarucu, Arapaima Gigas, at the Amazonian Varzea: Red Giants in Muddy Waters. Doctoral thesis, University of St. Andrews, Scotland, UK. 251p.

Rebelatto Junior, I. A.; Lima, A. F.; Rodrigues, A. P. O.; Maciel, P. O.; Kato, H. C. A.; Mataveli, M. et al. 2015. Reprodução e engorda do pirarucu: levantamento de processos produtivos e tecnologias. 1. ed. Embrapa, Brasília, 102p.

Rios-Cardenas, O.; Morris, M. R. 2009. Mating systems and strategies of tropical fishes. In: Claro, K.D.; Oliveira, P.S.; RicoGray, V. (Ed.). Tropical Biology and Conservation Management. v.3. EOLSS Publications, Paris, France, p.219-240.

Saint-Paul, U. 1986. Potential for aquaculture of South American freshwater fishes: a review. Aquaculture, 54: 205-240.

Sogabe, A.; Yanagisawa, Y. 2007. Sex-role reversal of a monogamous pipefish without higher potential reproductive rate in females. Proceedings of The Royal Society Biology, 274: 2959-2963.

RECEIVED: $12 / 05 / 2017$

ACCEPTED: 04/10/2017

ASSOCIATE EDITOR: Rodrigo do Valle 